\title{
FAKTOR-FAKTOR YANG BERPENGARUH TERHADAP KEBIJAKAN \\ HUTANG PERUSAHAAN \\ (Studi Empiris pada Perusahaan Manufaktur yang terdaftar di Bursa Efek Indonesia
}

Tahun 2012-2014)

\author{
Luluk Muhimatul Ifada \\ Yunandriatna \\ Universitas Islam Sultan Agung
}

\begin{abstract}
Debt policy is one of the most important decisions for the company. It is thus important to figure out the determinants of debt policy. The main purpose of this study is to examine the effect of the size, free cash flow, managerial ownership, dividend policy on debt policy of Indonesian manufacturing public listed firms. Data collected from 195 companies from 2012 to 2014 were analyzed using multiple regression. Current study found that free cash flow and managerial ownership have negative effect on the debt policy. Furthermore, the study also found that dividend policy and company size positively affects the debt policy.
\end{abstract}

Keywords: company size, debt policy, dividend policy, free cash flow, and managerial ownership.

\section{PENDAHULUAN}

Perusahaan yang melakukan pengembangan usaha akan mengalami berbagai hambatan terutama berkaitan dengan masalah pengambilan hutang. Kebijakan hutang merupakan pengambilan keputusan utama bagi perusahaan. Konsep agency theory menurut Hendriksen dan Van Breda (2000) dalam Setiawati (2010) adalah teori yang memberikan penjelasan mengenai hubungan antara principal dan agent. Principal memberikan pekerjaan kepada agen untuk melakukan pekerjaan termasuk pengambilan keputusan dari principal kepada agent. Teori keagenan memberikan pengertian keperluan manajemen dalam perusahaan dan keperluan investor dalam perusahaan tidak sama. Hal itu terjadi lantaran manajer mementingkan keperluan pribadi manajer. Biaya yang dikeluarkan oleh manajer mengakibatkan bertambahnya biaya perusahaan sehingga menurunkan laba perusahaan dan menurunkan dividen perusahaan.

Hal yang harus diperhatikan keputusan mengambil hutang yaitu dengan mempertimbangkan besarnya biaya tetap berupa bunga yang harus 
dibayar. Free cash flow adalah kas yang ada pada perusahaan kemudian disalurkan kepada investor (Ross et. al, 2002 dalam Hasan 2015). Free cash flow memberikan gambaran kepada pemegang saham bahwa dividen yang dibagikan oleh perusahaan tidak hanya untuk meningkatkan nilai perusahaan. Kepemilikan manajerial saham yang dimiliki perusahaan dari pihak manajemen perusahaan (Sujoko dan Soebiantoro, 2007 dalam Nurmasari, 2015). Dalam hal ini dijelaskan bahwa seorang manajer memiliki dua peran yaitu sebagai manajer dan sebagai investor. Kebijakan dividen adalah keputusan seberapa besar persentase dari pemasukan yang dimiliki perusahaan diberikan kepada investor (Brigham dan Houston, 2010 dalam Fandini, 2013). Ukuran perusahaan merupakan sesuatu yang digunakan untuk memutuskan kebijakan hutang. Perusahaan dengan ukuran besar memiliki kesempatan lebih dikenali masyarakat dibandingkan dengan perusahaan dengan ukuran kecil (Wahidahwati, 2002 dalam Syadeli 2013).

Masalah dari penelitian adalah adanya perbedaan antara keputusan manajer dan investor yang dapat mengakibatkan konflik yang di sebut agency conflict. Penelitian dilakukan pada perusahaan manufaktur. Perusahaan manufaktur merupakan suatu usaha yang memiliki kegiatan menjadikan bahan baku menjadi bahan jadi yang layak untuk dipasarkan. Alasan memilih perusahaan manufaktur karena skala produksinya besar dan dibutuhkan modal yang besar pula untuk pengembangan produk sehingga cenderung mempunyai tingkat hutang yang tinggi.

Berdasarkan uraian, maka penelitian ini digunakan untuk menjawab pertanyaan berikut ini: Apakah free cash flow, kepemilikan manajerial, kebijakan dividen, dan ukuran perusahaan berpengaruh pada kebijakan hutang?

Sesuai dengan masalah yang diuraikan, maka tujuan penelitian yaitu untuk mengetahui apakah terdapat pengaruh free cash flow, kepemilikan manajerial, kebijakan dividen, dan ukuran perusahaan pada kebijakan hutang.

\section{KERANGKA TEORITIS DAN PENGEMBANGAN HIPOTESIS}

\section{Pengembangan Hipotesis}

\section{Pengaruh Free Cash Flow pada}

\section{Kebijakan Hutang}

Free cash flow menggambarkan fleksibelnya anggaran pada perusahaan. Perusahaan dengan aliran kas bebas memiliki kelebihan prestasi jauh lebih 
patut untuk dijadikan sebagai gambaran sebagai perusahaan yang baik dibandingkan dengan perusahaan tidak memiliki aliran kas bebas dikarenakan perusahaan dapat menghasilkan laba atas berbagai kesempatan yang tidak dapat diperoleh oleh perusahaan yang tidak memiliki kelebihan aliran kas bebas sehingga enggan untuk menggunakan hutang.

White et al. (2003) dalam Mulianti (2010) dalam penelitiannya yang membuktikan free cash flow mempunyai pengaruh negatif signifikan pada kebijakan hutang. Hipotesis dirumuskan sebagai berikut:

H1: Free cash flow mempunyai pengaruh negatif pada kebijakan hutang.

\section{Pengaruh kepemilikan manajerial pada} kebijakan hutang

\section{Kepemilikan}

manajerial

merupakan saham yang dimiliki perusahaan, ikut dalam pengambilan keputusan perusahaan (Wahidahwati, 2002 dalam Rustendi, 2008). Kepemilikan manajerial akan menganggung konsekuensi dari kebijakan yang diambil sehingga manajer akan lebih waspada untuk mengabil keputusan mengenai penggunaan hutang. Kehati-hatian manajer dapat memberikan pengaruh terhadap kebijakan hutang.

Penelitian yang dilakukan Wahidahwati (2002) dalam Gusti (2011) menjelaskan kepemilikan manajerial mempunyai pengaruh negatif dan signifikan pada kebijakan hutang. Hipotesis dirumuskan sebagai berikut:

$\mathrm{H} 2$ : Kepemilikan manajerial mempunyai pengaruh negatif pada kebijakan hutang.

\section{Pengaruh kebijakan dividen pada kebijakan hutang}

Kebijakan dividen yaitu keputusan yang berhubungan dengan penggunaan keuntungan hak investor (Husnan, 2001 dalam Astutiningsih 2010). Perusahaan yang memiliki dividen tinggi lebih menyukai penyediaan dana menggunakan modal perusahaan internal sehingga pembayaran dividen menurunkan hutang.

Penelitian yang dilakukan Makaryanawati dan Mamdy (2009) dalam Junaidi (2012) menguji pengaruh kebijakan dividen terhadap kebijakan hutang, memberikan bukti bahwa kebijakan dividen mempunyai pengaruh negatif dan signifikan pada kebijakan hutang. Hipotesis dirumuskan sebagai berikut:

H3: Kebijakan dividen mempunyai pengaruh negatif pada kebijakan hutang. 
Pengaruh ukuran perusahaan pada kebijakan hutang

Ukuran perusahaan (size) merupakan keseluruhan aktiva milik perusahaan. Perusahaan besar mempunyai akses luas terhadap pendanaan internal maupun eksternal. Semakin besar ukuran perusahaan, diprediksikan memiliki tingkat hutang yang semakin tinggi. Perusahaan dengan ukuran kecil secara umum tidak memiliki posisi yang kuat terhadap hutang, disebabkan kapabilitasnya terhadap pinjaman terdapat ketentuan yang tidak boleh dilampaui.
Penelitian yang dilakukan Cristianti (2006) dalam Astuti (2013) menjelaskan ukuran perusahaan mempunyai pengaruh pada kebijakan hutang, hasil signifikan dan positif. Hipotesis dirumuskan sebagai berikut:

H4: Ukuran perusahaan mempunyai pengaruh positif pada kebijakan hutang

\section{Model Penelitian}

Untuk mengetahui keterikatan antar pengaruh variabel digambarkan suatu kerangka penelitian yang dapat dilihat pada gambar berikut ini:

\section{Gambar 1. Model Penelitian}

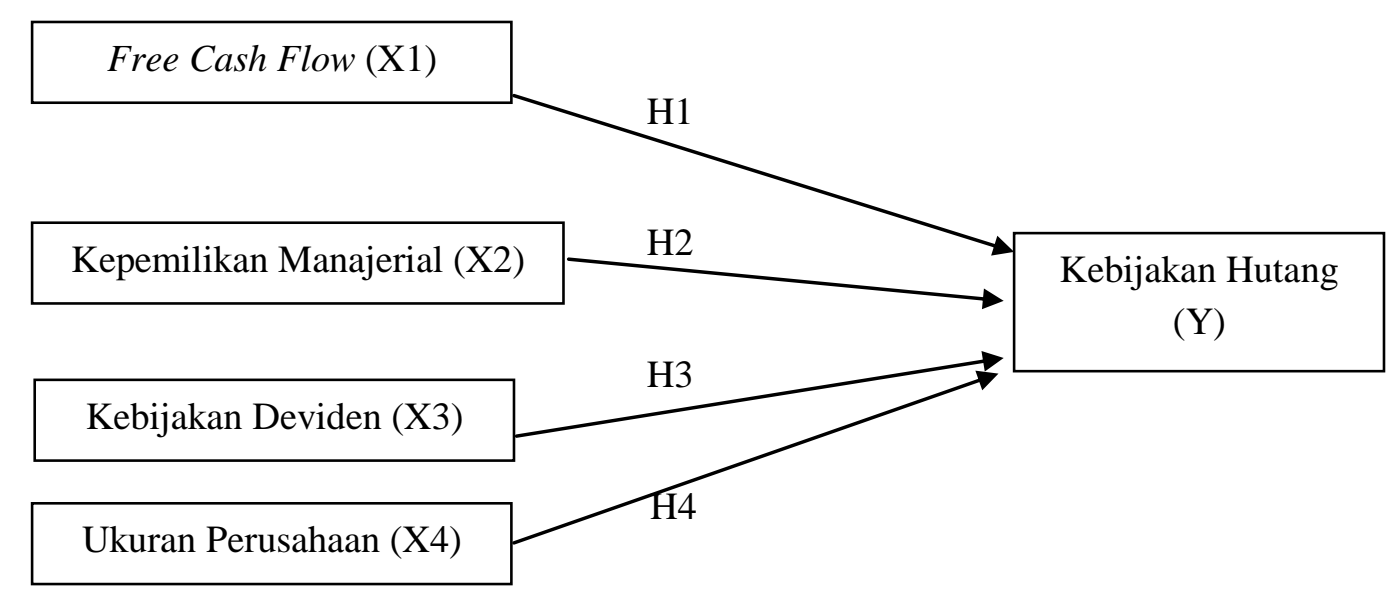

\section{METODE PENELITIAN}

\section{Populasi dan Sampel}

Populasi dan sampel yang digunakan merupakan semua perusahaan manufaktur yang terdaftar di Bursa Efek Indonesia tahun 2012-2014, dipilih menggunakan metode purposive sampling yaitu secara acak dengan kriteria sebagai berikut:

a. Perusahaan yang memberikan laporan keuangan kepada BEI yang berakhir pada tanggal 31 Desember untuk tahun buku 2012-2014. 
b. Perusahaan yang aktif menyampaikan laporan keuangan periode 2012-2014.

c. Perusahaan yang menyampaikan data laporan secara lengkap selama periode pengamatan tahun 2012-2014.

\section{Definisi Operasional Variabel}

\section{1). Free Cash Flow}

Ross et al. (2000) dalam Hasan (2015) menjelaskan aliran kas bebas merupakan kelebihan kas perusahaan, digunakan untuk membiayai segala proyek yang ada pada perusahaan yang memiliki nilai positif di masa yang akan datang. Menghitung free cash flow digunakan perhitungan Ross et al. (2000) dalam Hasan (2015), yaitu:

$$
\mathrm{FCF}_{\text {it }}=\mathrm{AKO}_{\text {it }}-\mathbf{P M}_{\mathrm{it}}-\mathrm{NWC}_{\text {it }}
$$

Keterangan:

$$
\begin{aligned}
& \mathrm{FCF}_{\text {it }}: \text { Free cash flow } \\
& \mathrm{AKO}_{\text {it }} \quad \text { : aliran kas operasi } \\
& \text { perusahaan i pada tahun } \mathrm{t} \\
& \mathrm{PM}_{\mathrm{it}} \quad \text { : pengeluaran modal } \\
& \text { perusahaan i pada tahun } \mathrm{t} \\
& \mathrm{NWC}_{\mathrm{it}} \quad \text { : modal kerja bersih } \\
& \text { perusahaan i pada tahun } \mathrm{t}
\end{aligned}
$$

\section{2). Kepemilikan Manajerial}

Wahidahwati (2002) Pithaloka (2009) menjelaskan bahwa managerial ownership merupakan saham yang dimiliki oleh pihak manajemen ikut serta untuk memutuskan kebijakan hutang. Managerial ownership dirumuskan sebagai berikut Wahidahwati (2002) dalam Pithaloka (2009), yaitu:

$$
\text { Managerial Ownership }(\text { MOWN })=\frac{\text { Jumlah saham beredar }}{\text { Total saham beredar }}
$$

\section{3). Kebijakan Dividen}

Gitman (2003) dalam Nugraha (2010) menjelaskan bahwa suatu kebijakan dividen pembayarannya berdasakan pada persentase tetap dari pendapat perusahaan. Menurut Gitman (2003) dalam Nugraha (2010) dapat dirumuskan sebagai berikut:

$$
\boldsymbol{D P R}=\frac{\text { Dividend Per Share Persentase }}{\text { Earnings Per Share }}
$$

\section{4). Ukuran Perusahaan}

Ukuran perusahaan ditentukan menggunakan log natural dari penjualan. Ukuran perusahaan yang diproksikan dengan size. Ukuran perusahaan dihitung menggunakan rumus Klapper dan Love (2002) dalam Oktafian (2015), yaitu:

$$
\text { SIZE }=\log \text { of total assets }
$$

\section{5). Kebijakan Hutang}

Hanafi (2005) dalam Hasan (2015) menjelaskan bahwa kebijakan hutang yaitu pengambilan keputusan untuk memperoleh dana eksternal perusahaan. Menurut Hanafi (2005) dalam Hasan (2015) kebijakan hutang dirumuskan sebagai berikut:

$$
\boldsymbol{D E R}=\frac{\text { Total Hutang }}{\text { Total Equity }}
$$

FAKTOR-FAKTOR YANG BERPENGARUH TERHADAP KEBIJAKAN HUTANG PERUSAHAAN

(Studi Empiris pada Perusahaan Manufaktur yang terdaftar di Bursa Efek Indonesia Tahun 2012-2014)

Luluk Muhimatul Ifada

Yunandriatna

Yuniversitas Islam Sultan Agung
Undriatna 
Keterangan :

$$
\begin{array}{lll}
\text { Total } & : & \text { Hutang Jangka Panjang } \\
\text { Hutang } & + \text { Hutang Jangka } \\
& \text { Pendek } \\
\text { Total Equity } \quad: & \begin{array}{l}
\text { Hutang Jangka Panjang } \\
+ \text { Hutang Jangka } \\
\end{array} \\
& \text { Pendek }
\end{array}
$$

\section{Teknik Analisis Data}

\section{Statistik Deskriptif}

Statistik deskriptif berfungsi

menggambarkan data untuk melihat median, mean, maksimum, minimum, dan deviasi standar.

\section{Uji Asumsi Klasik}

Uji asumsi klasik meliputi:

a. Uji Normalitas

b. Uji Multikolinearitas

c. Uji Autokorelasi

d. Uji Heteroskedastisitas

\section{Pengujian Hipotesis}

Pengujian hipotesis diukur dengan nilai statistik $t$, nilai statistik $f$, dan koefisien deteminasi.

\section{Metode Regresi Linier Berganda}

Metode analisis untuk mengetahui variabel independen yang mempengaruhi secara signifikan pada variabel dependen pada perusahaan manufaktur yang terdaftar di BEI tahun 2012-2014. Persamaan regresi linier berganda sebagai berikut:

$$
Y=\alpha+b_{1} X_{1}+b_{2} X_{2}+b_{3} X_{3}+b_{4} X_{4}+e
$$

\section{HASIL PENELITIAN DAN}

\section{PEMBAHASAN}

\section{Deskriptif Objek Penelitian}

Perusahaan yang digunakan dalam penelitian adalah perusahaan manufaktur go public terdaftar di BEI. Periode penelitian diambil tahun 2012-2014. Teknik analisis penelitian yang digunakan adalah purposive sampling. Dari total 65 perusahaan, waktu pengamatan 3 tahun diperoleh total data yang berjumlah 195 dan diperoleh 163 data yang terbebas dari outlier.

Berikut ini statistik deskriptif dari variabel yang dijadikan penelitian dapat dilihat pada tabel 1 .

\section{Uji Asumsi Klasik}

\section{a. Uji Normalitas}

Pengujian menggunakan Kolmogorov Smirnov dapat dilihat pada tabel 2 . Berdasarkan hasil tabel 2 hasil pengujian normalitas menunjukkan bahwa variabel independen terhadap variabel dependen terdistribusi secara normal. 
Tabel 1. Statistik Deskriptif

\begin{tabular}{|c|c|c|c|c|c|c|c|}
\hline & \multirow{2}{*}{$\begin{array}{c}\mathrm{N} \\
\begin{array}{c}\text { Statisti } \\
\mathrm{c}\end{array}\end{array}$} & \multirow{2}{*}{$\begin{array}{c}\text { Minimum } \\
\text { Statistic }\end{array}$} & \multirow{2}{*}{$\begin{array}{c}\text { Maximum } \\
\text { Statistic }\end{array}$} & \multirow{2}{*}{$\begin{array}{c}\text { Sum } \\
\begin{array}{c}\text { Statisti } \\
\text { c }\end{array}\end{array}$} & \multicolumn{2}{|c|}{ Mean } & \multirow{2}{*}{$\begin{array}{c}\text { Std. Deviation } \\
\text { Statistic }\end{array}$} \\
\hline & & & & & Statistic & Std. Error & \\
\hline $\begin{array}{l}\text { Ukuran } \\
\text { perusahaan }\end{array}$ & 195 & .11 & 9.71 & 550.17 & 2.8214 & .16310 & 2.27756 \\
\hline $\begin{array}{l}\text { Free cash } \\
\text { flow }\end{array}$ & 195 & .01 & 2.22 & 94.44 & .4843 & .03809 & .53190 \\
\hline $\begin{array}{l}\text { Kepemilikan } \\
\text { manajerial }\end{array}$ & 195 & .01 & 1.54 & 29.20 & 1.4697 & .02145 & .29952 \\
\hline $\begin{array}{l}\text { Kebijakan } \\
\text { dividen }\end{array}$ & 195 & .03 & 7.52 & 286.60 & & .07219 & 1.00808 \\
\hline $\begin{array}{l}\text { Kebijakan } \\
\text { hutang }\end{array}$ & 195 & & & & & & \\
\hline $\begin{array}{l}\text { Valid N } \\
\text { (listwise) }\end{array}$ & 195 & .04 & 44.71 & 316.92 & 1.6252 & .26078 & 3.64155 \\
\hline
\end{tabular}

Sumber : Data yang diolah sendiri dengan SPSS20, 2015

Tabel 2. Uji Normalitas

\begin{tabular}{|c|c|c|}
\hline \multicolumn{3}{|c|}{ One-Sample Kolmogorov-Smirnov Test } \\
\hline & & $\begin{array}{l}\text { Unstandardized } \\
\text { Residual }\end{array}$ \\
\hline \multicolumn{3}{|r|}{ 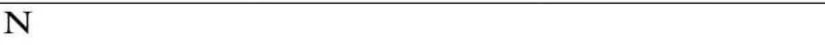 } \\
\hline & Mean & 163 \\
\hline Normal & Std. Deviation & .0203126 \\
\hline \multirow[t]{3}{*}{ Parameters ${ }^{\text {a,b }}$} & Absolute & .68537678 \\
\hline & Positive & .094 \\
\hline & Negative & .094 \\
\hline \multicolumn{2}{|c|}{ Kolmogorov-Smirnov Z } & -.083 \\
\hline \multicolumn{2}{|c|}{ Asymp. Sig. (2 tailed) } & .979 \\
\hline
\end{tabular}

Sumber: Data yang diolah sendiri dengan SPSS20, 2015

\section{b. Uji Multikolinearitas}

Hasil pengujian multikolinearitas dapat dilihat pada tabel 3.

Hasil pengujian pada tabel 3 menunjukkan bila pengujian tersebut tidak terjadi adanya gejala multikolinearitas.

\section{c. Uji Autokorelasi}

Pengujian dengan uji Durbin Watson (DW) hasil pengujian dapat dilihat pada tabel 4.

Hasil pengujian pada tabel 4 menunjukkan pengujian tersebut tidak terjadi problem autokorelasi. 
Tabel 4. Uji Autokorelasi

Model Summary

\begin{tabular}{|c|c|c|c|c|c|c|c|c|c|c|}
\hline \multirow{2}{*}{$\begin{array}{c}\text { Mode } \\
1\end{array}$} & \multirow[t]{2}{*}{$\mathrm{R}$} & \multirow{2}{*}{$\begin{array}{c}\mathrm{R} \\
\text { Squar } \\
\mathrm{e}\end{array}$} & \multirow{2}{*}{$\begin{array}{l}\text { Adjuste } \\
\text { d R } \\
\text { Square }\end{array}$} & \multirow{2}{*}{$\begin{array}{l}\text { Std. } \\
\text { Error of } \\
\text { the } \\
\text { Estimat } \\
\text { e }\end{array}$} & \multicolumn{5}{|c|}{ Change Statistic } & \multirow{2}{*}{$\begin{array}{c}\text { Durbin } \\
- \\
\text { Watson }\end{array}$} \\
\hline & & & & & $\begin{array}{c}\mathrm{R} \\
\text { Square } \\
\text { Chang } \\
\mathrm{e}\end{array}$ & $\begin{array}{c}\text { F } \\
\text { Chang } \\
\text { e }\end{array}$ & $\begin{array}{c}\mathrm{df} \\
1\end{array}$ & df2 & $\begin{array}{c}\text { Sig. F } \\
\text { Chang } \\
\text { e }\end{array}$ & \\
\hline 1 & $.304^{2}$ & .093 & .074 & 3.50505 & .093 & 4.851 & 4 & $\begin{array}{r}19 \\
0\end{array}$ & .001 & 2.078 \\
\hline
\end{tabular}

a. Predictors: (Constant), kebijakan dividen, kepemilikan manajerial, free cash flow, ukuran perusahaan b. Dependent Variable: kebijakan hutang

Sumber : Data yang diolah sendiri dengan SPSS20, 2015

\section{d. Uji Heterokedastisitas}

\section{Uji Grafik Scatter Plot}

Berikut hasil pengujian Grafik Scatter Plot dapat dilihat pada gambar 2.
Berdasarkan pada gambar terlihat dapat disimpulkan pengujian variabel independen terhadap variabel dependen telah memenuhi persyaratan heteroskedastisitas

Gambar 2. Uji Grafik Scatter Plot

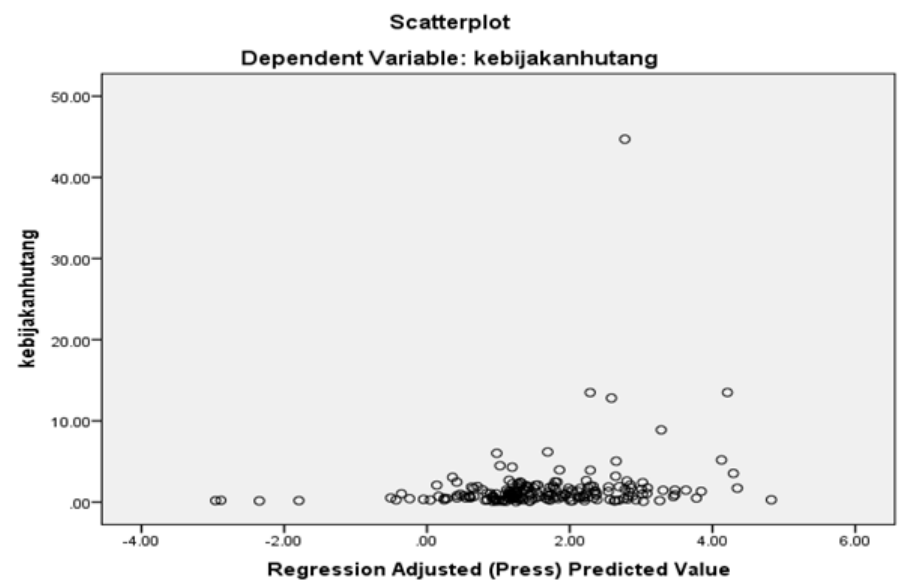

Sumber : Data yang diolah sendiri dengan SPSS20, 2015

\section{Uji Glejser}

Dalam penelitian ini, uji heteroskedastisitas dilakukan menggunakan uji glejser dapat dilihat pada tabel 5.
Berdasarkan hasil pengujian dapat diketahui nilai signifikasi variabel bebas dalam penelitian ini $>0,05$, sehingga modal regresi tidak terjadi heteroskedastisitas. 
Tabel 5. Uji Glejser

Coefficients $^{\mathrm{a}}$

\begin{tabular}{lrrrrr}
\hline Model & \multicolumn{2}{c}{$\begin{array}{c}\text { Unstandardized } \\
\text { Coefficients }\end{array}$} & $\begin{array}{l}\text { Standardized } \\
\text { Coefficients }\end{array}$ & $\mathrm{t}$ & Sig. \\
\cline { 2 - 6 } & \multicolumn{1}{c}{$\mathrm{B}$} & Std. Error & \multicolumn{1}{c}{ Beta } \\
\hline (Constant) & & & .122 & & \\
\hline Ukuran perusahaan & 1.522 & .602 & .042 & 1.180 & .241 \\
Free cash flow & .278 & .056 & -.062 & 1.150 & .234 \\
Kepemilikan & .888 & .099 & -.066 & 4.37 & .463 \\
Manajerial & -.754 & .846 & & -.891 & .374 \\
Kebijakan dividen & -.675 & .090 & & -8.40 & .403 \\
\hline
\end{tabular}

a. Dependent Variable: kebijakan hutang

Sumber : Data yang diolah sendiri dengan SPSS20, 2015

\section{UJI HIPOTESIS}

\section{a. Uji Parsial (Uji Statistik t)}

\section{Pengujian hipotesis 1}

Hasil pengujian regresi linier berganda antara free cash flow terhadap kebijakan hutang dapat diartikan bahwa free cash flow tidak mempunyai pengaruh signifikan pada kebijakan hutang. Penjelasan dapat diartikan semakin tinggi free cash flow, maka semakin rendah perusahaan dalam menggunakan hutang. Hal ini berarti hipotesis pertama diterima.

Menurut Ismawati (2009) dalam Rahmawati (2012) bahwa perusahaan yang memiliki kelebihan aliran kas bebas akan memiliki tenaga kerja yang lebih patut untuk djadikan gambaran dibandingkan perusahaan yang tidak memiliki kelebihan aliran kas bebas sebab perusahaan dapat mendapatkan laba dari berbagai kemungkinan peluang yang tidak dapat diperoleh perusahaan yang tidak memiliki kelebihan aliran kas bebas sehingga perusahaan enggan untuk menggunakan hutang.

Hasil penelitian mendukung penelitian White et al. (2003) dalam Mulianti (2010) yang memberikan bukti bahwa variabel free cash flow mempunyai pengaruh negatif signifikan pada kebijakan hutang, yang menjelaskan apabila dalam suatu perusahaan memiliki free cash flow tinggi, maka semakin baik kondisi perusahaan dikarenakan perusahaan tersebut memiliki aliran kas bebas yang tersedia yang digunakan untuk perkembangan perusahaan.

\section{Pengujian hipotesis 2}

Hasil pengujian regresi linier berganda antara kepemilikan manajerial terhadap kebijakan hutang diartikan

FAKTOR-FAKTOR YANG BERPENGARUH TERHADAP KEBIJAKAN HUTANG PERUSAHAAN

(Studi Empiris pada Perusahaan Manufaktur yang terdaftar di Bursa Efek Indonesia Tahun 2012-2014)

Luluk Muhimatul Ifada

Yunandriatna

Universitas Islam Sultan Agung 
kepemilikan manajerial tidak signifikan pada kebijakan hutang. mempengaruhi kebijakan hutang perusahaan. Hal ini berarti hipotesis kedua ditolak.

Pecking order hypothesis menjelaskan perusahaan lebih memilih penyediaan dana yang bersumber dari dana dalam perusahaan daripada berasal dari dana luar perusahaan dalam aktivitas pendanaan. Apabila dana yang berasal dari dalam perusahaan tidak mencukupi maka digunakan dana yang berasal dari dana luar perusahaan. Urutan penggunaan dana adalah laba ditahan, kemudian hutang, yang terakhir adalah penerbitan ekuitas baru (Puspita, 2009). Hal ini menunjukkan kebijakan hutang yang terjadi pada perusahaan manufaktur di Indonesia tidak terpengaruh oleh adanya pemilik saham yang mempunyai kedudukan di manajemen perusahaan. Penelitian ini didukung pecking order hypothesis bahwa kebijakan hutang tidak terpengaruh oleh saham yang dimiliki perusahaan oleh pihak manajemen (Makmun, 2003 dalam Puspita 2009).

\section{Pengujian hipotesis 3}

Hasil pengujian regresi linier berganda antara kepemilikan manajerial terhadap kebijakan hutang dapat diartikan kebijakan dividen berpengaruh positif 
perusahaan akan tertarik untuk meminjam dana sehingga hutang akan bertambah.

\section{Pengujian hipotesis 4}

Hasil pengujian regresi linier berganda antara ukuran perusahaan terhadap kebijakan hutang dapat diartikan ukuran perusahaan berpengaruh positif signifikan pada kebijakan hutang. Penjelasan dapat diartikan bahwa semakin tinggi ukuran perusahaan, maka semakin tinggi aktivitas operasinya, semakin tinggi modal yang dibutuhkan sehingga semakin tinggi perusahaan dalam menggunakan hutang. Hal ini berarti hipotesis keempat diterima.

Perusahaan besar memiliki aktiva cukup besar yang dapat digunakan untuk jaminan dalam pendanaan perusahaan (Phitaloka, 2009). Hal ini menunjukkan bahwa semakin besar perusahaan dapat memberikan kemudahan akses pencarian dana dari sumber hutang karena perusahaan mempunyai collateral assets. Dengan demikian, semakin besar ukuran perusahaan, maka semakin besar kesanggupan perusahaan dalam mendapatkan keuntungan, dan semakin banyak kebutuhan akan modalnya yang berasal dari dana eksternal.

Hasil penelitian ini mendukung Cristianti (2006) dalam Astuti (2013) ukuran perusahaan mempunyai pengaruh positif dan signifikan pada kebijakan hutang. Memberikan penjelasan bahwa semakin besar aktiva tetap yang dimiliki oleh perusahaan akan mempermudah akses pendanaan dari sumber hutang.

\section{a. Uji Simultan (Uji Statistik F)}

Hasil pengujian dapat diartikan variabel independen bersama-sama berpengaruh secara signifikan pada variabel dependen. Oleh karena itu, dapat digunakan untuk memprediksi penelitian dimasa yang akan datang. Hasil pengujiannya dapat dilihat pada tabel 6.

Tabel 6. Uji Statistik F

\begin{tabular}{|c|c|c|c|c|c|c|}
\hline \multicolumn{2}{|c|}{ Model } & Sum of Squares & $\mathrm{df}$ & Mean Square & $\mathrm{F}$ & Sig. \\
\hline \multirow{3}{*}{1} & Regression & 238.390 & 4 & 59.598 & 4.851 & $.001^{\mathrm{b}}$ \\
\hline & Residual & 2334.221 & 190 & 12.285 & & \\
\hline & Total & 2572.612 & 194 & & & \\
\hline
\end{tabular}

Sumber : Data yang diolah sendiri dengan SPSS20, 2015 
Tabel 7. Koefisien Determinasi $\left(\mathrm{R}^{2}\right)$

\begin{tabular}{lll}
\hline $\mathrm{R}$ & $\mathrm{R}$ Square & Adjusted R Square \\
\hline $.304^{\mathrm{a}}$ & .093 & .074 \\
\hline
\end{tabular}

Sumber : Data yang diolah sendiri dengan SPSS20, 2015

\section{b. Koefisien Determinasi $\left(\mathbf{R}^{2}\right)$}

Hasil pengujiannya dapat dilihat pada tabel 7. Nilai koefisien determinasi untuk variabel independen memberikan pengertian bahwa variabel dependen mampu menjelaskan $7,4 \%$ sedangkan sisanya diterangkan oleh variabel lain yang tidak diamati dalam penelitian.
Model Persamaan Regresi Linier

\section{Berganda}

Uji regresi menggunakan SPSS versi 20 dapat dilihat pada tabel 8 .

Berdasarkan tabel tersebut, maka diperoleh model regresi sebagai berikut:

$\mathrm{Y}=1,522+0,278 \mathrm{X} 1-0,035 \mathrm{X} 2-$
$0,025 \mathrm{X} 3+0,723 \mathrm{X} 4$

Tabel 8. Hasil Regresi

Coefficients $^{\mathrm{a}}$

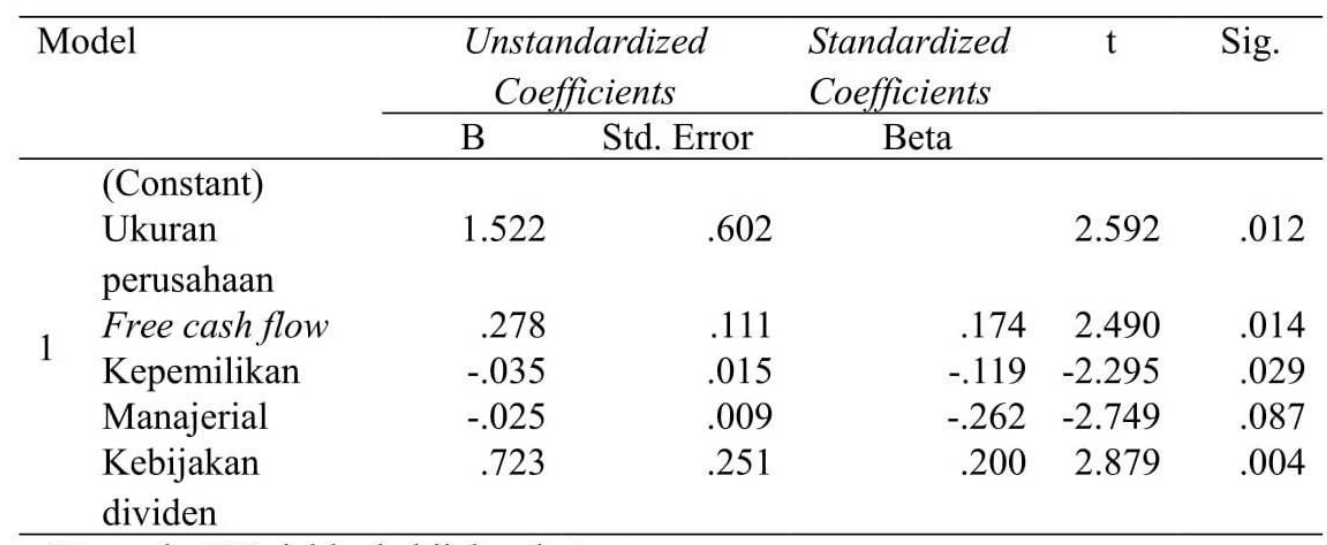

a. Dependent Variable: kebijakan hutang

Sumber : Data yang diolah sendiri dengan SPSS20, 2015

SIMPULAN, IMPLIKASI, DAN 1. Hasil penelitian menunjukkan free

\section{KETERBATASAN}

Simpulan

Hasil penelitian dan pembahasan sebelumnya, selanjutnya dapat disimpulkan sebagai berikut: cash flow mempunyai pengaruh negatif dan signifikan pada kebijakan.

2. Hasil penelitian menunjukkan kepemilikan manajerial tidak mempunyai pengaruh pada kebijakan hutang. 
3. Hasil penelitian menunjukkan kebijakan dividen mempunyai pengaruh positif dan signifikan pada kebijakan hutang.

4. Hasil penelitian menunjukkan ukuran perusahaan mempunyai pengaruh positif dan signifikan pada kebijakan hutang.

\section{Implikasi}

1. Obyek penelitian hanya mengambil pada perusahaan manufaktur, untuk itu sebaiknya perlu menambah obyek penelitian.

2. Sebaiknya pada penelitian selanjutnya menggunakan data dengan periode yang lebih panjang sehingga akan menghasilkan nilai Adjusted $R$ Square yang lebih tinggi.

\section{Keterbatasan}

1. Pemilihan sampel dilakukan dengan purposive sampling.

2. Penelitian ini hanya dalam periode tiga tahun.

3. Dalam penelitian ini hanya menggunakan empat variabel independen.

\section{DAFTAR PUSTAKA}

Astuti, Elly. 2013. "Pengaruh Kepemilikan Institusional,
Profitabilitas, Ukuran Perusahaan Terhadap Kebijakan Hutang Perusahaan di Indonesia". Tesis, Program Pascasarjana. Universitas Negeri Solo.

Astutiningsih. 2010. "Pengaruh Perubahan Laba Terhadap Perubahan Dividen Perusahaan (Studi Empiris Pada Perusahaan Manufaktur yang Terdaftar di BEI)". Skripsi, Program Sarjana. Universitas Muhammadiyah Surakarta.

Fandini, Fanny Rosa. 2013. "Pengaruh Profitabilitas dan Struktur Kepemilikan Terhadap Nilai Perusahaan Dengan Keputusan Investasi, Keputusan Pendanaan dan Kebijakan Dividen Sebagai Variabel Moderasi (Studi Pada Perusahaan Pertambangan Yang Terdaftar Di BEI)". Skripsi, Program Sarjana, Universitas Pasundan.

Gusti, Bertha Firyanni. 2011. "Pengaruh Free Cash Flow dan Struktur Kepemilikan Saham Terhadap Kebijakan Hutang Dengan Investment Opportunity Set Sebagai Variabel Moderating (Studi Empiris Pada Perusahaan Manufaktur yang Terdaftar di BEI)". Padang: Fakultas Ekonomi Universitas Negeri Padang.

Hasan, Mudrika Alamsyah. 2015. "Pengaruh Kepemilikan Manajerial, Free Cash Flow, dan Ukuran Perusahaan Terhadap Kebijakan Hutang (Studi Pada PerusahaanPerusahaan Industri Dasar dan Kimia yang Terdaftar di BEI)". Riau: Fakultas Ekonomi Universitas Riau.

FAKTOR-FAKTOR YANG BERPENGARUH TERHADAP KEBIJAKAN HUTANG PERUSAHAAN

(Studi Empiris pada Perusahaan Manufaktur yang terdaftar di Bursa Efek Indonesia Tahun 2012-2014)

Luluk Muhimatul lfada

Yunandriatna

Universitas Islam Sultan Agung 
Junaidi, Akhmad Afif. 2012. "Analisis Pengaruh Free Cash Flow, Struktur Kepemilikan, Kebijakan Dividen, Struktur Aktiva, dan Profitabilitas Terhadap Kebijakan Hutang Perusahaan". Semarang: Fakultas Ekonomi dan Bisnis Universitas Dian Nuswantoro.

Mulianti, F.M. 2010. "Analisis Faktorfaktor yang Mempengaruhi Kebijakan Hutang dan Pengaruhnya terhadap Nilai Perusahaan (Studi pada Perusahaan Manufaktur yang Terdaftar di Bursa Efek Indonesia (BEI) Perioda Tahun 2004-2007)". Tesis, Program Pascasarjana Universitas Diponegoro, Semarang.

Nugraha, Diky Fahmi. 2010. "Pengaruh Kebijakan Dividen, Kebijakan Leverage dan Biaya Agensi Terhadap Kepemilikan Manajerial Pada Sektor Perbankan yang Terdaftar di Bursa Efek Indonesia Periode 2003-2007”. Skripsi, Program Sarjana. Universitas Widyatama Bandung.

Nurmasari, Nuraini Dest. 2015. "Pengaruh Kepemilikan Manajeria, Kepemilikan Konstitusional, Kebijakan Dividen, Pertumbuhan Perusahaan, dan Profitabilitas Terhadap Kebijakan Hutang Perusahaan (Studi Empiris Pada Perusahaan Manufaktur yang Terdaftar di BEI)". Simposium Nasional Akuntansi.

Oktafian, Mohammad Triangga Yudith. 2015. "Pengaruh Corporate Governance Terhadap Return On Equity Pada Perusahaan yang Terdaftar Di Bursa Efek Indonesia (Studi Kasus Pada 14 Perusahaan Go Public yang Menduduki
Peringkat CGPI Tahun 2010-2012)”. Salatiga: STIE AMA Salatiga.

Phitaloka, Nina Diah. 2009. "Pengaruh Faktor-Faktor Intern Perusahaan Terhadap Kebijakan Hutang: Dengan Pendekatan Pecking Order Theory”. Skripsi, Program Sarjana. Universitas Lampung.

Puspita, Fira. 2009. "Analisis FaktorFaktor yang Mempengaruhi Kebijakan Dividend Payout Ratio (Studi Kasus Pada Perusahaan Yang Terdaftar Di Bursa Efek Indonesia Periode 2005-2007)". Tesis, Program Pascasarjana. Universitas Diponegoro.

Rahmawati, Apriliana Nuzul. 2012. "Analisis Faktor Kebijakan Hutang yang Mempengaruhi Nilai Perusahaan (Studi Pada Perusahaan Manufaktur yang Terdaftar di BEI Periode 2006-2010". Skripsi, Program Sarjana. Universitas Diponegoro.

Rustendi, Tedi. 2008. "Pengaruh Hutang dan Kepemilikan Manajerial Terhadap Nilai Perusahaan Pada Perusahaan Manufaktur (Survey Pada Perusahaan Manufaktur yang Tercatat Di Bursa Efek Jakarta)". Jurnal Akuntansi FE Unsil. Vol. 3 No. 1, 2008.

Setiawati, Koosrini. 2010. "Pengaruh Rasio Camel Terhadap Praktik Manajemen Laba di Bank Umum Syariah". Skripsi, Program Sarjana. Universitas Diponegoro.

Syadeli. 2013. "Struktur Kepemilikan, Profitabilitas, dan Ukuran Perusahaan Terhadap Kebijakan Hutang Perusahaan Pemanufakturan Di Bursa Efek Indonesia”. Jurnal 
Manajemen dan Akuntansi. Vol 2, Nomor 2. 2 Agustus 2013.

Yuniarti, Ahadiyah Muslida Dewi. 2013. "Pengaruh Kepemilikan Manajerial, Dividen, Profitabikitas, dan Struktur Aset Terhadap Kebijakan Hutang". Accounting Analysis Journal. AAJ 2 (4) (2013). 